\title{
The impact of tree species on soil productivity
}

\author{
Constant Pieter van Goor
}

National Forest Service, P.O. Box 20020, 3502 LA Utrecht, Netherlands

Key words: soil productivity, forest influences, plantation management

\section{Summary}

The impact of tree species on soil productivity forms part of the system of effects and influences of management in man-made forests. Research instigated to ascertain the causes of the die-back and reduced growth in forests in Central and Western Europe at the end of the 19th century and later indicated that the influence of fast-growing conifers such as Norway spruce and Scots pine was deleterious. Originally it was assumed that these species caused soil productivity to decrease, but later more sophisticated research methods revealed that management activities such as terrain and soil preparation largely controlled the tree's effect on the soil.

An important aspect is the improvement in soil productivity observed after soils impoverished by man (such as heathland soils, peat soils and abandoned agricultural land) have been afforested.

Finally, proposals for experiments to determine quantitatively the impact of tree species on soil productivity are put forward.

\section{Scope of the problem}

The problem of ascertaining how a tree species affects soil productivity is not isolated but forms part of the framework of the effects of man-made forests on forest ecosystems. Changes in the soil that result from forest management should never affect the soil productivity negatively. Management generally comprises preparing the terrain, establishing the plantation, tending, thinning and harvesting. These practices affect the vegetation and the soil conditions. Individual tree species also have an effect on soil: this is achieved by their litter, their root activity and their associated micro-climate.

The natural processes of forest ecosystems also affect soil productivity. Nutrients from the atmosphere enter the soil directly or via the vegetation and simultaneously nutrients are lost by leaching, erosion and volatilization.

The problem of the impact of tree species on soil productivity has been studied for many years. Since the beginning of this century, countless publications have appeared, first in Europa and later on in other parts of the world. Therefore no reference will be made in the following text to the existing literature, but a selected bibliography on the subjects will be appended. The list is restricted to recent literature, including several reviews. 


\section{Present state of knowledge}

Forestry as a regular kind of land-use began in Central Europe in the middle of the 18 th century and became important from the 19 th century onwards. Since the 18 th century the area of man-made forests in Central Europe has been greatly increased and many of the forest ecosystems of today are far from natural. Particularly in the 19 th century and the first decades of the 20th century, fast-growing tree species were planted on unsuitable sites. Furthermore, because the practice of afforestation was in its infancy, vast quantities of tree seeds were transported from one region to another, and races that were not adapted to unfamiliar conditions were mistakenly planted.

Calamities of large-scale die-back of forests and serious decrease of growth inevitably occurred. Spruces, Scots pine and silver fir were particularly affected. Of course, the reasons for these setbacks became the focus of research programmes. It soon became evident that neither insects, fungi, nor other pathogens were the primary cause of the die-back and poor growth, but that the cause was probably the adverse influence of the tree species on the soil.

Much research was done to ascertain the properties of litter and the form of humus and their significance for soil processes. The so-called raw humus under conifer stands was considered to be deleterious to soil fertility. It was thought that raw humus made nutrients unavailable for the trees and that because the $\mathrm{pH}$ fell, podsolization was accelerated.

Although this hypothesis could nout be confirmed - the facilities for research were rather primitive at the time - it was recommended to make more use of indigenous tree species or to mix the fast-growing exotic species with soil-improving hardwood species in the crown layer, or by underplanting.

In the middle of the 20th century, liming was applied to increase humification and biological activity in the soil with the aim of preventing the formation of raw humus. Specific silvicultural methods were advocated, such as partially removing raw humus to stimulate regeneration, or intensive soil cultivation combined with fertilization and green manuring or interplanting with nitrogen-fixing crops and shrubs. When more sophisticated methods for research became available, better understanding of the problem developed rapidly. The prevailing opinion about the adverse effect of tree species on soil fertility could not be confirmed by results of systematic research. Die-back of forests and decrease of growth with succesive generations of Norway spruce and Scots pine apparantly had other causes. It became evident that management had a much more far-reaching impact than the tree species. On sandy soils the increase of biological activity, e.g. by complete cultivation, whether or not combined with liming and fertilization, was found to result in a serious loss of soil organic matter under certain conditions. The studies done by Wittich around 1920 in northern German sandy forest soils are classic. He found that plantations of Scots pine initially developed well on completely cultivated soils, but that after some twenty years their performance was surpassed by the plantations on partially cultivated soils.

A critical analysis of the related European studies up to mid-1950s by an IUFRO 
working party could not establish any evidence for tree species having an adverse effect on soil. In those cases where such a negative impact had been supposed other influences appeared to be decisive. In certain cases, the sites of the trials with different species were not comparable; in others different treatment of the soil had been involved, for instance cultivation or burning. The interaction of difference of races was sometimes confusing, particularly with Scots pine. It was concluded that the effect of an exotic species did not differ from the influence of the indigenous species as far as the negative effect on soil productivity concerns.

In Western Europe it is therefore now generally accepted that for reforestation or regeneration the soil should be disturbed as little as possible. No complete cultivation is applied. To overcome subsequent problems of competition from vegetation, chemical weed control was introduced. Later, chemical weed control was reduced because of its undesirable environmental effects. Subsequently, the quality of planting stock was adapted. Unexpectedly, it was found that soil productivity increased in afforestations of previously unforested land. On impoverished soils heath, peat, abandoned agricultural land - trees had a positive effect on soil productivity. Here too, the question was whether this effect was caused by the trees or by the change in microclimate following the afforestation and whether different tree species produce different effects. This question has not yet been answered.

It is evident that when impoverished soils are afforested the nitrogen content is boosted, even if the tree species used do not themselves fix nitrogen. After one generation of forest an improvement in soil productivity can already be observed. In heath afforestations in the Netherlands, the rate of growth of a second generation of forest is generally $30 \%$ faster than of a first generation of forest. Furthermore, a clear vegetational succession is evident. Recently, research on nitrogen fixation under forests, in particular by bacteria, algae and fungi associated with coniferous species, has been intensified.

On these impoverished soils no negative effect of complete soil cultivation has been observed during the establishment of the first forest generation. However, the improvement in soil condition during the first generation can be nullified if the soil is fully cultivated for the regeneration of the next generation of forest.

In Western and Central Europe the problem of maintaining soil productivity and the role of tree species in this respect no longer form an important topic for research. Given the accelerating conversion elsewhere in the world (particularly in the tropics and subtropics) from natural forests to man-made forests with fast-growing species and the increasing activity in afforesting waste land in these regions, this problem of maintaining soil productivity is currently receiving much attention. But since there is a certain degree of comparability between forests in different parts of the world, these scientists should endeavour to ascertain and exploit the state of knowledge and the experience gained in Europe. European experience indicates that management activities are crucial to the dynamics of the forest ecosystem and that the phase of ecological development in the forest determines the magnitude of the effect of management. 


\section{Ecological development of forest ecosystems}

The strategy adopted for forest management, especially in the case of man-made forests, depends on the way the forest ecosystem has developed. The development phase of a forest ecosystem strongly influences which processes will take place in the ecosystems of man-made forests: it will dictate the management activities that will not endanger the maintenance of soil productivity.

There are many conceivable starting-points of ecological development at which forestry management can begin. They can be combined in three broad groups:

1. The original (natural) forest is present and is to be converted into man-made plantations;

2. The original forest was converted into man-made plantations long ago;

3. The vegetation is not composed of trees, or was impoverished by man long ago.

For these starting-points, a forestry strategy with man-made plantations generally has the following consequences.

In the first group of forest ecosystems, a kind of equilibrium exists. By converting the original forest ecosystem into a man-made ecosystem, the following are the minimum changes that can be expected:

- interruption of the supply of organic matter to the soil for a short period. The way organic matter cycle is affected also depends on the methods used to prepare terrain and soil;

- the supply of new organic matter is qualitatively affected;

- the root activity of the original vegetation cover is disturbed;

- the micro-climate is affected;

- the forest ecosystem is changed.

However, when the conversion of the natural stands into man-made stands is carried out very carefully, without damaging the soil by cultivation, burning or logging, adverse effects will be minimized, especially when the choice of tree species is restricted to indigenous species. But even when exotic species are used, there may not be any appreciable adverse effect, provided the above-mentioned care is observed. Yet, when conversion of the forest is accompanied with intensive terrain preparation, such as burning or cultivation, soil productivity will undoubtedly be jeopardized. On soils with a great reserve of minerals, however, such as young alluvial or volcanic soils, the risks will be far less than on more developed soils or sandy soils.

In the second group of ecological starting-points there is also a kind of equilibrium, albeit with man as an essential factor of the forest ecosystem. No changes will occur as long as existing management is continued.

As in the preceding group, negative affects can be avoided if management activities do not change the abiotic environment irrevocably. It is not clear to what extent various tree species will influence soil productivity permanently.

It is assumed that when man-made forests of the final group of ecological starting points have been growing for more than 200 years on impoverished soils, a kind of equilibrium has developed. When a first stand is established, the ecological situation changes dramatically. This change includes: 
- the range of the amplitude of climatic factors is considerably reduced by the development of a microclimate, and thus the conditions for the edaphon improve;

- the supply of organic matter increases both in amount and quality;

- root activity increases: soil penetration, input of organic matter and soil biology improve;

- nitrogen content is improved as a result of enhanced nitrogen fixation.

The changes in the ecosystem brought about by afforestation are considerable and mostly beneficial. It is important to prevent incorrect management activities from interfering with this positive development of the ecosystem.

\section{The impact of tree species}

Although in the preceding section it was made clear that the impacts of forest management on soil productivity greatly exceed the effect of the trees, the different species must have differing effects. Many species differ in their root activity, litter, impact on micro-climate and biological soil activity and these differences might become evident as species-specific influence on soil processes and thus on soil productivity.

But although much research has been done to try to quantify the specific impact of tree species on soil productivity, no general concensus has been achieved. The extreme complexity of the dynamics of forest soils has not always been sufficiently taken into account, which is why there is great controversy in the literature.

If the specific influence of tree species on soil productivity is to be ascertained, other influences have to be eliminated. Comparing soil conditions under different tree species to find out if there is a difference between the species should be carried out on fully comparable soils, under fully comparable management regimes and under comparable ecological conditions. Any effects identified must subsequently be tested by growth experiments with one or more tree species on the plots that have been compared. So far, this kind of research has never been done: only parts of the problem have been studied.

But how should such research be carried out? First, one should select a site covered with a natural forest vegetation and without any appreciable present or historical influence from man, such as grazing or litter removal. On such a site the tree species to be studied should be planted after the original forest vegetation has been removed. Some of the original vegetation should be retained for comparison. The preparation of the terrain and the soil must be carried out in the same way on all plots. All treatments have to be equal on all plots.

After the establishment of the stands, all changes in the various plots have to be monitored.

At the end of the experiment, when the trees in the various plots are fully grown, the stands are felled, chipped on the spot, and left in the plots. Subsequently, each plot is planted with one or more tree species, whose growth is monitored to ascertain how much the previously planted species has influenced the soil productivity. Test trees are also planted on the part of the experiment where the original forest was left as the control. 
Such an experiment should show whether individual tree species have a specific influence on soil productivity. Differences may occur in the soil conditions under the stands during the growth of the trees, but these are no proof of the impact of a tree species on soil productivity.

Such a long-term study will require much time and continuity, and therefore foresters have tried to find short-cuts. Unfortunately, although these short-cuts provide much information, they have not revealed whether individual tree species do have an impact on soil productivity.

\section{References}

Adedeji, F. O., 1984. Nutrient cycles and successional changes following shifting cultivation practice in moist semi decidious forests in Nigeria. Forest Ecology and Management 9: 87-99.

Alban, D. H., 1982. Effects of nutrient accumulation by aspen, spruce and pine on soil properties. Journal of the Soil Science Society of America 46(4): 853-861.

Anonymous, 1981. Australian Forest Nutrition Workshop Productivity in Perpetuity. Proceedings Australian Forest Nutrition Workshop.

Ballard, R. \& S, P. Gessel (Eds.), 1983. IUFRO Symposium on forest site and continuous productivity (1982). General Technical Report NW Forest and Range Experiment Station USDA Forest Service No PNW-163.

Bednall, B. H., 1968. The problem of lower volumes associated with second rotations in Pinus radiata plantations in South Australia. Woods and Forests Department, South Australia, Bulletin No 17.

Berg, B. \& H. Staaf, 1981. Leaching, accumulation and release of nitrogen in decomposing forest litter. Swedish University of Agricultural Sciences S-75007: 163-178.

Binkley, D., 1984. Does forest removal increase rates of decomposition and nitrogen release. Forest Economics and Management 8 (3/4): 229-233.

Binkley, D., J. F. Kimmins \& M. C. Feller, 1982. Water chemistry profiles in an early- and a mid-successional forest in coastal British Columbia. Canadian Journal of Forest Research 12(2): 240-248.

Bormann, B. T. \& D. S. De Bell, 1980. Nitrogen content and other soil properties related to age of red alder stands. Journal of the Soil Science Society of America 45(2): 428-432.

Brasell, H. M. \& D. F. Sinclar, 1983. Elements returned to forest floor in two rainforests and three plantation plots in tropical Australia. Journal of Ecology 71(2): 367-378.

Burg, J. van den, 1979. Veranderingen in heidegronden door bebossing. Nederlands Bosbouw Tijdschrift 51(10): 223-230.

Chyicke, E. O., 1980. Impact on soils of fast growing species in lowland humid tropics. FAO Forestry Papers 21.

Crane, W. J. B. \& R. J. Raison, 1980. Removal of phosphorus in logs, when harvesting Eucalyptus delegatensis and Pinus radiata forests on short and long rotation. Australian Forestry 43(4): 253-260.

Davay, C. B. \& A. G. Wollum, 1979. Nitrogen input to forest ecosystems through biological fixation. Proceedings 'Impact of intensive harvesting on forest nutrient cycling': 62-74.

Driessen, P. M., P. Buurman \& Permadhy, 1976. The influence of shifting cultivation on a podzolic soil from central Kalimantan. Proceedings ATA 106 Seminar Soil Research Institute Bogor: 95-115.

Ellis, R. C. \& A. A. Graley, 1983. Gains and losses in soil nutrients associated with harvesting and burning eucalypt rain forest. Plant and Soil 74(3): 437-450.

Ellis, R., R. K. Lowry \& S. K. Davis, 1982. The effect of regeneration burning upon the nutrient status of soil in two forest types in Southern Tasmania. Plant and Soil 65(2): 171-186.

Eyk-Bos, C. van \& W. Terwel, 1977. Groei-onderzoek Pinus nigra in de boswachterij Schoorl. Rapport 'De Dorschkamp', Wageningen No 105.

Fanta, J., 1982. Natuurlijke verjonging van bossen op droge zandgronden. Rapport 'De Dorschkamp', Wageningen No 301.

Feller, M. C., 1981. Waterbalances in Eucalyptus regnans, E. obliqua and Pinus radiata forests in Victoria. Australian Forestry 44(3): 153-162.

Flinn, D. W., R. O. Squire \& P. W. Farrell, 1980. The role of organic matter in the maintenance of site 
productivity on sandy soils. New Zealand Journal of Forestry 52(2): 229-236.

Florence, L. Z. \& F. D. Cook, 1984 . Asymbiotic $\mathrm{N}_{2}$-fixing bacteria associatied with three boral conifers. Canadian Journal of Forest Research 14(4): 595-596.

Ford, E. D., D. C. Malcolm \& J. Atterson (Eds.), The ecology of even-aged forest plantations. Proceedings of Division IUFRO September 1978.

Fox, J. E. D., 1984. Rehabilitation of mined lands. Forestry Abstracts (45/9): 565-600.

Gay, G. \& J. P. Garrec, 1980. Premier essais de microlocalisation de quelques élements minéraux dans les racines courtes et les mycorhized de Pinus halepensis Mill. Comptes rendus hebdomadaires des Séances de l'Académie des Sciences, D 290(1): 69-71.

Goor, C. P. van, 1977. Trends in forestry research and its implication on silviculture. Irish Forestry $34(2): 62-76$

Hällbom, L. \& B. Bergman, 1979. Influence of certain herbicides and forest fertilization on the nitrogen fixation by the lichenpelligera pretextata. Oecologia 40/1: 19-27.

Helliwell, D. R., 1982. Options in forestry. Uitgever?

Howard, P. J. A. \& D. M. Howard, 1982. Soil change through afforestation. Institute Terrestrial Ecology, Annual Report, p. 101.

Holmsgaard, E., H. Holstener-Jörgensen \& A. Yde-Anderson, 1961. Bodenbildung, Zuwachs und Gesundheitszustand von Fichtenbeständen erster und zweiter Generation. Nord-Seeland. Forstl. Forsöksv. Danmark No 27.

Johnson, N. E., 1976. Biological opportunities and fast growing plantation. Journal of Forestry 74: 206-211.

Jordan, C. F., 1980. Nutrient leaching from agro-ecosystems in the amazon basin and implications for recovery of the forest. In: Tropical ecology and development, pp. 553-559. International Society of Tropical Ecology.

Keeney, D. R., 1980. Prediction of soil nitrogen availability in forest ecosystems: a literature review. Forest Science 26(1): 159-171.

Keeves, A., 1966. Some evidence of loss of productivity with succesive rotations of Pinus radiata in the South East of South Australia. Australian Forestry 30(1): 51-63.

$\mathrm{Li}, \mathrm{C}$. H., 1981. The nutrient balance of soil under chinese fir plantation and broad leaved mixed forest. Acta Pedologica Sinica 18(3): 255-261.

Lundgren, B., 1978. Soil conditions and nutrient cycling under natural and plantation forest in Tanzanian Highlands. Reports in Forest Ecology and Forest Soils No 31. Swedisch University of Agricultural Sciences.

Malcolm, D. C., 1979. Some effects of the first rotation on site properties. Irish Forestry 36(2): 76-88.

Malajezuk, N., R. Molina \& J. M. Trappe, 1982. Ectomycorrhiza formation in Eucalyptus. 1. Pure culture synthesis, host specificity and mycorrhizal compatibility with Pinus radiatia. New Physiologist 91(3): 467-482.

Miles, J. A. et al., 1981. Soil compaction - machine system. The proceedings of the symposium on engineering systems for forest regeneration: 71-122. American Society of Agricultural Engineering.

Nebe, W., 1979. Zur Auswirkung von Biomassenützungen in Fichten- und Kiefernbeständen auf den Nährelementenkreislauf. Beiträge für den Forstwirtschaft 13(4): 152-159.

Nihlgărd, B., 1971. Pedological influence of spruce planted on former beech forest soils in Scania, South Sweden. Oikos 22: 302-314.

Nys, C., 1981. Modifications des caractéristiques physico-chimiques d'un sol brun acide des Ardennes primaires par la monoculture d'epicea. Annales des Sciences forestières 38(2): 237-258.

Page, G., 1968. Some effects of conifer crips on soil properties. Commonwealth Forestry Review 47: $52-62$.

Parmentier, G. \& J. Reinade, 1981. Production de litière et dynamisme de retour au sol de élements minéreaux par l'intermédiaire des feuilles de hère et des aiguilles d'epicea en Haut Ardenne. Revue d'Ecologie et de Biologie du Sol 18(2): 159-177.

Robinson, R. K., 1973. Mycorrhizas and 'Second rotation decline' of Pinus patula in Swaziland. South African Forestry Journal (84): 16-19.

Stone, E. L., 1975. Effects of species on nutrient cycles and soil change. Philosophical Transactions Royal Society, Series B 271: 149-162.

Tamm, C. O., 1979. Nutrient cycling and procuctivity of forest ecosystems. Proceedings 'Impact of in-

Neth. J. agric. Sci. 33 (1985) 


\section{P. VAN GOOR}

tensive harvesting on forest nutrient cycling': 2-21.

Whitehead, D., 1982. Ecological aspects of natural and plantation forest. Forestry Abstracts 43(10): 615-624.

Zinke, P. J., A. G. Slangenberger, M. J. Fox, B. W. Parker \& R. G. Stone, 1982. Elemental drain of fertility from a sierra mixed conifer forest site due to intensive harvest of fuels. California Forestry Note 82. 